\title{
Increased leishmanicidal activity of alveolar macrophages from mature horses with mild equine asthma
}

D.A.B. Lessa https://orcid.org/0000-0002-7123-8265 N.X. Alencar https://orcid.org/0000-0002-0151-4746 R.A. Torres Filh https://orcid.org/0000-0003-4047-4932 M.F.M. Costa https://orcid.org/0000-0001-5302-571X g/0000-0002-5101-8687 https://orcid.org/0000-0002-6388-5286

[Aumento da atividade leishmanicida de macrófagos alveolares de equinos adultos com asma equina leve]

\author{
D.A.B. Lessa ${ }^{1}$, N.X. Alencar ${ }^{1}$, R.A. Torres Filho ${ }^{1}$, M.F.M. Costa ${ }^{2}$, \\ W.R. Fernandes ${ }^{3}$, E.M. Saraiva ${ }^{4}$
}

${ }^{1}$ Faculdade de Veterinária, Universidade Federal Fluminense - Niterói, RJ

${ }^{2}$ Universidade Severino Sombra - Vassouras, RJ; Wintec, Wiakato Institute of Technology, Hamilton New Zealand

${ }^{3}$ Faculdade de Medicina Veterinária e Zootecnia, Universidade de São Paulo - São Paulo, SP

${ }^{4}$ Instituto de Microbiologia Paulo de Góis, Universidade Federal do Rio de Janeiro - Rio de Janeiro, RJ

\begin{abstract}
Alveolar macrophages (AMs) are an essential part of defense mechanisms within the lungs and their phagocytic activity is important for organ homeostasis. The phagocytic ability of AMs obtained from bronchoalveolar lavage from 17 mature mixed-breed pleasure horses ( 8 healthy and 9 diagnosed with mild equine asthma) was studied through assays with Leishmania (Viannia) braziliensis promastigotes, which enabled the calculation of a phagocytic index (PI) and a survival index (SI). Results indicate that phagocytic activity of AMs in asthma affected horses is similar to healthy horses, while leishmanicidal activity is significantly increased in horses with asthma.
\end{abstract}

Keywords: horses, equine asthma, alveolar macrophage, phagocytosis, Leishmania (Viannia) braziliensis

\section{RESUMO}

Os macrófagos alveolares (MAs) são uma parte essencial dos mecanismos de defesa dentro dos pulmões e sua atividade fagocítica é importante para a homeostase desse órgão. A capacidade fagocitária dos MAs obtidos do lavado broncoalveolar de 17 equinos adultos, sem raça definida (oito saudáveis e nove com diagnóstico de asma equina leve), foi estudada por meio de ensaios com promastigotas de Leishmania (Viannia) braziliensis. Foi calculado o índice fagocítico e o índice de sobrevivência. Os resultados indicam que a atividade fagocítica de MAs em cavalos com asma é semelhante a cavalos saudáveis, enquanto a atividade leishmanicida está significativamente aumentada em cavalos com essa enfermidade.

Palavras-chave: cavalos, asma equina, macrófago alveolar, fagocitose, Leishmania (Viannia) braziliensis

\section{INTRODUCTION}

Alveolar macrophages (AMs) are the front line of cellular defense against respiratory pathogens and inhaled particles in the lungs (Karagianni et al., 2013). Intense exposure to air pollutants is an important risk factor for Inflammatory airways disease (mild equine asthma) in urban policing horses (Lessa et al., 2011). Particle deposition in the alveolar tissue affects the lungs' function

Recebido em 13 de abril de 2018

Aceito em 9 de novembro de 2018

E-mail: daniellessa@id.uff.br
(Tetley, 2002), therefore lungs have a particle clearance system to minimize it. This system is highly dependent on phagocytic activity, and both AMs and neutrophils are involved in particle depuration of the lower airway (Oberdörster, 1988; Lehnert, 1992).

The equine AMs' phagocytosis has been studied in healthy horses (Mori et al., 2001; Muehlmann et al., 2012; Karagianni et al., 2013), and in several conditions, including Recurrent Airway Obstruction (RAO) (Olszewski and Laber 1993; 
Tremblay et al., 1993; Franchini et al., 1998) and Inflammatory airways disease (IAD) (Michelotto et al., 2010), renamed recently to severe and mild equine asthma syndrome, respectively (Couëtil et al., 2016).

Leishmania (Viannia) braziliensis preferentially infects macrophages and the direct relationship between leishmanicidal activity and macrophage activation state is well known in murine macrophages in Leishmania (Viannia) braziliensis infection models (Evans et al., 1993, Assreuy et al., 1994 e Mukbel et al., 2007, Giudice et al., 2012, Ghosh et al., 2014). Phagocytosis of Leishmania (Viannia) braziliensis promastigotes depends on interactions between macrophage receptors, Leishmania (Viannia) braziliensis surface antigens and soluble serum components (Ueno and Wilson, 2012).

Since Leishmania (Viannia) braziliensis infects horses in Brazil (Vedovello Filho et al. 2008), the protocol of infection of murine peritoneal macrophages (PM) as described by Pinto-daSilva et al. (2002) was used, but murine PM were replaced by equine AMs.

The role of AMs in the pathogenesis of equine asthma syndrome is still poorly defined (Hughes et al., 2011), therefore studying phagocytic and microbicidal capacity of AMs in these horses is yet another step toward understanding the pathogenesis of the condition, as well as to formulate future treatment strategies based on the modulation of macrophage activation status.

In order to investigate alveolar macrophage activation status in horses diagnosed with mild asthma, AMs collected from the airways of healthy and affected horses were cultivated with Leishmania (Viannia) braziliensis and their ability to phagocytize and kill the parasites was compared.

\section{MATERIALS AND METHODS}

All procedures were approved by the Committee for Animal Care and Use of the Universidade Federal Fluminense, Niterói, Brazil (protocol number 124/2011). All animals were kept in stalls without bedding for 6 to 15 hours per day and the remaining time in paddocks. Horses were fed pelleted feed, grass hay and fresh grass, were vaccinated and dewormed regularly. The daily exercise routine was light to moderate. No horses in either group had undergone treatment for, nor exhibited signs of, airway inflammation in the two months prior to the commencement of the study.

Seventeen mature mixed-breed pleasure horses (6 females and 11 geldings, mean age 15.2 \pm 3.4 years) were used in this study. Eight horses belonging to the Brazilian Army were considered healthy (the control group) and nine police horses from Rio de Janeiro, Brazil (PMERJ) were classified as the asthma-affected group, based on clinical examination, tracheobronchoscopy, pulmonary function tests (maximum change in pleural pressure, $\Delta \mathrm{P}_{\text {Plmax }}$ ) and bronchoalveolar lavage cytology.

The asthma-affected horses used in this study were mature pleasure horses and may be classified as mildly affected according to criteria previously published (Lessa et al., 2011, Sad et al., 2013, Couëtil et al., 2016). Horses were classified as healthy when they had no abnormal clinical findings, no abnormalities at endoscopy, a $\Delta \mathrm{P}_{\text {PImax }} \leq 4 \mathrm{~cm} \quad \mathrm{H}_{2} \mathrm{O}$ according to criteria established by Deegen and Klein (1987) and bronchoalveolar lavage fluid (BALF) cytology with neutrophils $<5 \%$, eosinophils $<1 \%$ and mast cells $<2 \%$ (Mazan, 2010). Horses were included in the asthma-affected group if they demonstrated the following: $\Delta \mathrm{P}_{\mathrm{Plmax}} \leq 4 \mathrm{~cm} \mathrm{H}_{2} \mathrm{O}$, grade 1 to 2 (Gerber et al., 2004) tracheal secretions, and BALF cytology with neutrophils $>5 \%$. Some of the horses in this group (5/9) also demonstrated increased bronchovesicular sounds. All horses had hematology and fibrinogen profiles within normal ranges for the species according to the literature (Jain, 1993).

The AMs were obtained by bronchoalveolar lavage using a catheter (Equine Bronchoalveolar Lavage Catheter ${ }^{\circledR}$, Bivona, Smiths Medical PM, Inc.) as described by Hoffman and Viel (1997), where bronchoalveolar fluid was obtained by infusing $250 \mathrm{~mL}$ of $0.9 \%$ saline at $37^{\circ} \mathrm{C}$ into one of the lungs and immediately retrieving it by aspiration with a syringe. The BALF was centrifuged at $450 \mathrm{~g}$ for $12 \mathrm{~min}$ at $4{ }^{\circ} \mathrm{C}$, and the cell pellet was re-suspended in RPMI 1640 (Gibco BRL) supplemented with $10 \%$ heat inactivated Fetal Calf Serum (FCS, Hyclone Lab. Inc. Logan, Utah, USA), 100IU/mL penicillin and $100 \mu \mathrm{g}$ streptomycin $/ \mathrm{mL}$. Cell viability 
(80\%) was determined by Trypan blue exclusion counted in a Neubauer chamber. Bronchoalveolar lavage fluid in RPMI-FCS was seeded at $5 \times 10^{6}$ cells $/ \mathrm{mL}$ in sterile $13 \mathrm{~mm}$ coverslips (Glasstécnica $\left.{ }^{\circledR}\right)$ inside a 24 well cellculture plate (Costar $\left.{ }^{\circledR}\right)$ and incubated at $37^{\circ} \mathrm{C}$, $5 \% \mathrm{CO}_{2}$ for 1 hour to allow $\mathrm{AM}$ adhesion. The coverslips were then washed with sterile PBS at $37^{\circ} \mathrm{C}$ to remove unattached cells, $300 \mu \mathrm{L}$ RPMIFCS was added, and cultures were incubated overnight at $37^{\circ} \mathrm{C}$ at $5 \% \mathrm{CO}_{2}$.

Leishmania (Viannia) braziliensis promastigotes (MHOM/BR94/H3456) were cultivated in Schneider's Insect Medium (Sigma), supplemented with $10 \%$ heat-inactivated FCS and $40 \mathrm{mg} / \mathrm{mL}$ of gentamicin (Sigma), at $26^{\circ} \mathrm{C}$ for 5-7 days, after which the parasites reached the stationary-phase. The promastigotes were washed with PBS, and centrifuged at $2760 \mathrm{~g}$ for $10 \mathrm{~min}$, three times. The pellet was then resuspended in RPMI and incubated with AMs at a ratio of $10: 1$ parasite to $\mathrm{AM}$, and cultures incubated at $37^{\circ} \mathrm{C}, 5 \% \mathrm{CO} 2$ for $1 \mathrm{~h}$ to allow parasite uptake and adhesion. For these experiments AMs were assayed after $1 \mathrm{~h}$. Cultures were washed with PBS, fixed with methanol, stained with Giemsa and mounted on glass slides with Permount (Fisher Scientific, NJ, USA) after dehydration in acetone/xylene. The number of Leishmania (Viannia) braziliensis and the percentage of AMs adhered/phagocytosed to parasite were determined by counting 200 cells in duplicate cultures.
A phagocytic index (PI) for each horse was calculated by multiplying the percentage of AMs which had phagocytosed Leishmania (Viannia) braziliensis by the number of parasites per AM as previously described by Pinto-da-Silva et al. (2002). All the PIs were then added and divided by the number of horses to obtain the mean PI. In order to determine parasite survival, after $1 \mathrm{~h}$ of incubation, cultures were washed with PBS to remove free parasites, RPMI-FCS was added and the cells were incubated at $37^{\circ} \mathrm{C}, 5 \% \mathrm{CO} 2$ for 48h. Results were expressed as a mean percentage of parasite survival (survival index, SI), comparing PIs of each horse after $1 \mathrm{~h}$ interaction $(100 \%)$ in relation to $48 \mathrm{~h}$, in quadruplicate cultures (Pinto-da-Silva et al., 2002). Data was analyzed by ANOVA at $5 \%$ significance level.

\section{RESULTS AND DISCUSSION}

To the best of the authors' knowledge the data reported here is the first to compare the phagocytic activity and killing ability of AMs from healthy and asthma-affected mature horses. The percentage of AMs that adhered/phagocytosed Leishmania (Viannia) braziliensis $(\mathrm{P}=0.17)$, the number of parasite per AMs $(\mathrm{P}=0.50)$, and PI $(\mathrm{P}=0.21)$ were not significantly different between healthy and asthma-affected horses (Table 1).

Table 1. Phagocytic activity of equine alveolar macrophages

\begin{tabular}{lcccc}
\hline Group & N & $\begin{array}{l}\text { Particles } \\
\text { adhered/phagocytosed }(\%) \\
(\mathrm{P}=0.17)\end{array}$ & $\begin{array}{l}\text { Number of } \\
\text { particles/macrophages } \\
(\mathrm{P}=0.50)\end{array}$ & $\begin{array}{c}\text { Phagocytic } \\
\text { Index }\end{array}$ \\
& 8 & $41.22 \pm 13.77^{\mathrm{a}}$ & $1.86 \pm 0.33^{\mathrm{b}}$ & $80.45 \pm 43.10^{\mathrm{c}}$ \\
Healthy & 9 & $32.39 \pm 11.67^{\mathrm{a}}$ & $1.77 \pm 0.22^{\mathrm{b}}$ & $58.73 \pm 25.53^{\mathrm{c}}$ \\
\hline Asthma-affected & 9 & &
\end{tabular}

Results are expressed as mean \pm standard deviation (SD). In order to obtain the mean phagocytic index (PI), the PIs of all horses were added and divided by the number of horses. Same letters in the same column indicate lack of statistically significant differences ( $p$-values are indicated in the table).
Phagocytosis depends on engagement of particles through receptor-mediated binding which precedes internalization and induction of cellular antimicrobial responses (Rieger et al., 2010) and in the case of Leishmania (Viannia) braziliensis promastigotes it depends on interactions between macrophage receptors (CR1, CR3, MR and FnR), Leishmania (Viannia) braziliensis surface antigens (GP63, LPG and an 
unknown ligand) and soluble serum components, such as: C3, C3b, iC 3b, Factor I and Fibronectin (Ueno and Wilson, 2012). It can be hypothesized that the lack of differences in macrophage response between healthy and asthma-affected horses seen in the present work indicates that the asthmatic state does not promote a change in AMs surface receptors.

The leishmanicidal activity of murine macrophages is directly related to their activation state and production of $\mathrm{NO}$ and intermediate reactive oxygen radicals such as peroxide (Evans et al., 1993; Assreuy et al., 1994; Giudice et al., 2012, Mukbel et al., 2007, Ghosh et al., 2014). Nitric oxide (Michelotto et al., 2010) and peroxide (Mori et al., 2001) were previously detected in equine $\mathrm{AMs}$ and were related to increased activation state.

In this work it was not possible to detected NO and peroxide (data not shown) to confirm activation state. The observed decrease in parasite SI in the AMs after $48 \mathrm{~h}$ was higher $(\mathrm{P}=$ 0.0041 ) in asthma-affected horses than in healthy ones (Table 2). It was likely due to high microbicidal activity, which represents a higher activation state of the cells in this group, as previously seen for murine macrophages (Evans et al., 1993; Assreuy et al., 1994; Giudice et al., 2012, Mukbel et al. 2007, Ghosh et al., 2014). Results from the present work indicate that phagocytic capacity for Leishmania (Viannia) braziliensis is unaltered in horses with mild asthma while leishmanicidal activity is significantly increased.

Table 2. Leishmania (Viannia) braziliensis survival index (SI) in equine alveolar macrophages

\begin{tabular}{ccc}
\hline Group & N & Leishmania SI \\
\hline Healthy & 8 & $43.1 \pm 19.70^{\mathrm{b}}$ \\
Asthma-affected & 9 & $18.15 \pm 9.77^{\mathrm{a}}$ \\
\hline
\end{tabular}

Results are expressed as mean \pm SD of parasite survival comparing phagocytic indices of each horse after $1 \mathrm{~h}$ interaction $(100 \%)$ in relation to $48 \mathrm{~h}$, in quadruplicate cultures. Different letters in the same column mean the differences are statistically significant (ANOVA, P= 0.004).
The activation status of AMs in healthy horses was previously reported (Mori et al., 2001). Since exposure to dust has already been described as a cause of stimulation of alveolar macrophages (Franchini et al., 1998), it is expected that AMs might be already activated, even in healthy animals. This reflects the microenvironment within which these cells reside, and their inherent biological properties within such an environment. Unlike peritoneal macrophages (PMs), AMs from healthy horses have demonstrated efficient phagocytic activity for marked E. coli particles, and they are more activated than the PMs when stimulated with pro-inflammatory binders (Karagianni et al., 2013). A specific particle challenge was not conducted in this study; therefore, it is not possible to establish if airborne particle exposure resulted in direct macrophage function shift or in inflammation which in turn shifted macrophage function secondarily. In order to investigate these aspects, AM function after particle challenges and in natural viral or bacterial infection could be studied.

The difference in SI between healthy AMs and those obtained from horses with cytology compatible with airway inflammation should be further investigated using different methods than those described in this research before definite conclusions can be drawn.

\section{REFERENCES}

ASSREUY, J.; CUNHA, F.Q.; EPPERLEIN, M. et al. Production of nitric oxide and superoxide by activated macrophages and killing of Leishmania major. Eur. J. Immunol., v.24, p.672-676, 1994.

COUËTIL, L.L.; CARDWELL, J.M.; GERBER, V. et al. Inflammatory airway disease of horses-revised consensus statement. J. Vet. Intern. Med., v.30, p.503$515,2016$.

DEEGEN, E.; KLEIN, H.K. Intrapleural pressure measurement and bronchial spasmolysis tests in the horse performed with a transportable oesophageal pressure measuring instrument. Pferdeheilkund, v.3, p.213-221, 1987.

EVANS, T.G.; THAI, L.; GRANGER, D.L.; HIBBS, JR., J.B. Effect of in vivo inhibition of nitric oxide production in murine leishmaniasis. J. Immunol., v.151, p.907-915, 1993

VEDOVELLO FILHO, D.V.; JORGE, F.A.;

LONARDONI, M.V. et al. Zoonoses Public Health, v.55, p.149-155, 2008. 
FRANCHINI, M.; GILLI, U.; AKENS, M.K. et al. The role chemotactic cytokines in the pathogenesis of equine Chronic Obstructive Pulmonary Disease (COPD). Vet. Immunol. Immunopathol., v.66, p.53-65, 1998.

GERBER, V.; STRAUB, R.; MARTI, E. et al. Endoscopic scoring of mucus quantity and quality: Observer and horse variance and relationship to inflammation, mucus viscoelasticity and volume. Equine Vet. J., v.36, p.576-582, 2004.

GHOSH, J.; GUHA, R.; DAS, S.; ROY, S. Liposomal cholesterol delivery activates the macrophage innate immune arm to facilitate intracellular Leishmania donovani killing. Infect. Immun., v.82, p.607-617, 2014

GIUDICE, A.; VENDRAME, C.; BEZERRA, C. et al. Macrophages participate in host protection and the disease pathology associated with Leishmania braziliensis infection. BMC Infect. Dis., v.12, p.1-9, 2012.

HOFFMAN, A.M.; VIEL, L. Techniques for sampling the respiratory tract of horses. Vet. Clin. N. Am. Equine Pract., v.13, p.463-475, 1997.

HUGHES, K.J.; NICOLSON, L.; COSTA, N. et al. Evaluation of cytokine mRNA expression in bronchoalveolar lavage cells from horses with inflammatory airway disease. Vet. Immunol. Immunopathol., v.140, p.82-89, 2011.

JAIN, N.C. (Ed.). Essentials of veterinary hematology. Philadelphia: LEA and FEBIGER, 1993. 417p.

KARAGIANNI, A.E.; KAPETANOVIC, R.; MCGORUM, B.C. et al. The equine alveolar macrophage: functional and phenotypic comparisons with peritoneal macrophages. Vet. Immunol. Immunopathol., v.155, p.219-228, 2013.

LEHNERT, B.E. Pulmonary and thoracic macrophage subpopulations and clearance of particles from the lung. Environ. Health Perspec., v.97, p.17-46, 1992.

LESSA, D.A.B.; JORGE, M.L.L.A.; VIANA, E.B. et al. Análise do líquido broncoalveolar de equinos portadores de doença inflamatória das vias aéreas. Braz. J. Vet. Res. Anim. Sci., v.48, p.123-130, 2011.

MAZAN, M.R. Inflammatory airway disease in the horse. In: AMERICAN ASSOCIATION EQUINE PRACTITIONERS FOCUS ON UPPER AND LOWER RESPIRATORY DISEASES, 2010, Salt Lake City. Proceedings... Salt Lake City: AAEP, 2010. p.100-106.

MICHELOTTO Jr., P.V.; MUEHLMANN, L.A.; ZANATTA, A.L. et al. Platelet-activating factor and evidence of oxidative stress in the bronchoalveolar fluid of Thoroughbred colts during race training. $J$. Vet. Intern. Med., v.24, p.414-419, 2010.

MORI, E.; MORI, C.M.C.; FERNANDES, W.R. Avaliação da função de macrófagos alveolares em cavalos clinicamente sadios. Arq. Bras. Med. Vet. Zootec., v.53, p.172-178, 2001.

MUEHLMANN, L.A.; MICHELOTTO Jr., P.V.; NUNES, E.A. et al. PAF increases phagocytic capacity and superoxide anion production in equine alveolar macrophages and blood neutrophils. Res. Vet. Sci., v.93, p.393-397, 2012.

MUKBEL R.M.; PATTEN Jr., C.; GIBSON, K. et al. Macrophage killing of Leishmania amazonensis amastigotes requires both nitric oxide and superoxide. Am. J. Trop. Med. Hyg., v.76, p.669-675, 2007.

OBERDÖRSTER, G. Lung clearance of inhaled insoluble and soluble particles. J. Aerosol. Med., v.1, p.289-330, 1988.

OLSZEWSKI, M.; LABER, G. Production of free oxygen radicals by phagocytes from respiratory tract lavaged as well as from peripheral blood of horses with Chronic Obstrutive Pulmonary Disease (COPD) in comparison to healthy animals. Wien. Tierarztl. Monatsschr., v.80, p.332-337, 1993.

PINTO-da-SILVA, L.H.; CAMURATE, M.; COSTA, K.A. et al. Leishmania (Viannia) braziliensis metacyclic promastigostes purified using Bauhinia purpurea lectin are complement resistant and highly infective for macrophages in vitro and hamsters in vivo. Int. J. Parasitol., v.2, p.1371-1377, 2002.

RIEGER, A. M.; HALL, B. E.; BARREDA, D. R. Macrophage activation differentially modulates particle binding, phagocytosis and downstream antimicrobial mechanisms, Developmental \& Comparative Immunology, v.34, no.11, p. 1144-1159, 2010.

SAD, E.P.; LENCAR, N.X.; VISCARDI, V. et al. Cytology profile and age influence in the equine bronchoalveolar lavage in healthy and asymptomatic inflammatory airway disease. Cienc. Rural, v.43, p.52$455,2013$.

TETLEY, T.D. Macrophages and the pathogenesis of COPD. Chest, v.121, p.156S-159S, 2002.

TREMBLAY, G.M.; FERLAND, C.; LAPOINTE, J.M. et al. Effect of stabling on bronchoalveolar cells obtained from normal and COPD horses. Equine Vet. J., v.25, p.194-197, 1993

UENO, N.; WILSON, M.E. Receptor-mediated phagocytosis of Leishmania: implications for intracellular survival. Trends Parasitol., v.28, p.335344, 2012. 